\title{
Update van de behandeling van urineweginfecties bij honden en katten
}

\author{
Update on the treatment of urinary tract infections in dogs and cats
}

${ }^{1}$ F. Mortier, ${ }^{1}$ S. Marynissen, ${ }^{2}$ E. Stock, ${ }^{1}$ S. Daminet, ${ }^{1} \mathrm{D}$. Paepe

${ }^{1}$ Vakgroep Kleine Huisdieren

${ }^{2}$ Vakgroep Medische Beeldvorming van de Huisdieren en Orthopedie van de Kleine Huisdieren, Faculteit Diergeneeskunde, Universiteit Gent, Salisburylaan 133, 9820 Merelbeke, België

Femke.Mortier@UGent.be

\section{AMENVATTING}

Doorgaans worden bacteriële urineweginfecties bij kleine huisdieren beduidend langer behandeld met antibiotica dan bij mensen en het vermoeden bestaat dat urineweginfecties bij honden en katten volgens de oorspronkelijke internationale richtlijnen uit 2011 te lang worden behandeld. Naast kosten voor de eigenaar en mogelijke bijwerkingen voor het dier brengt dit het risico op de ontwikkeling van antibioticumresisentie bij dier en mens met zich mee. In 2019 zijn er nieuwe richtlijnen van de "International Society for Companion Animal Infectious Diseases" verschenen over de diagnose en behandeling van bacteriële urineweginfecties bij honden en katten. Het doel van dit artikel is om een overzicht te geven van de aangewezen behandeling (i. e. keuze van het antibioticum en duur van de therapie) bij de verschillende types bacteriële urine-weginfectie bij kleine huisdieren. Ook worden praktische tips meegegeven voor het definitief vaststellen van een urineweginfectie. Zo wordt in de eerste plaats zekerheid verkregen over de aanwezigheid van een bacteriële infectie als oorzaak van de aanwezige klachten en kan vervolgens ook een weloverwogen keuze worden gemaakt qua antibioticum, gebaseerd op het type urineweginfectie en het antibiogram. Ook de rol van niet-steroïdale ontstekingsremmers in de behandeling van lagere-urinewegklachten, in afwachting van het resultaat van een urinecultuur, wordt besproken. Tot slot is het belangrijk te beseffen dat niet elke positieve urinecultuur noodzakelijkerwijs een antibioticumtherapie inhoudt.

\section{ABSTRACT}

The duration of antimicrobial treatment of bacterial urinary tract infections in small animals is usually longer than in human medicine and there is a suspicion that the duration of treatment in dogs and cats as advised in the 2011 guidelines may be too long. Longer treatment duration causes a higher cost for the owner and potentially more side effects for the pet, as well as an increased risk for the development of antimicrobial resistance in animals and people. In 2019, new guidelines were published by the 'International Society for Companion Animal Infectious Diseases' on the diagnosis and management of bacterial urinary tract infections in dogs and cats. The aim of the present article is to provide an overview of the recommended treatment (choice of antimicrobial drug and duration of therapy) for the different types of bacterial urinary tract infection in small animals. Also, practical tips are given to definitively diagnose a urinary tract infection. In that way, first certainty can be obtained about the presence of a bacterial infection as the cause of the clinical signs present, and subsequently, a welladvised antibiotic choice can be made based on the type of urinary tract infection and the antimicrobial susceptibility pattern. The role of non-steroidal anti-inflammatory drugs in controlling lower urinary tract signs, while awaiting urine culture results, is discussed. Last but not least, it is important to realize that not every positive urine culture should lead to antimicrobial therapy. 


\section{INLEIDING}

Bacteriële urineweginfecties (UWI) zijn een vaak voorkomend probleem bij honden en katten en vormen een van de meest voorkomende redenen waarom antibiotica bij deze diersoorten worden ingezet (Weese et al., 2019). De nadelen van onnodige antibioticumtherapie (indien de klachten niet bacterieel van oorsprong zijn of in het geval van subklinische bacteriurie (SKB - zie infra) of incorrect gebruik van antibiotica (verkeerde productkeuze, te korte of te lange therapieduur) zijn echter niet te onderschatten (Byron, 2019). Zo leidt onnodige antibioticumtherapie tot de ontwikkeling van antibioticumresistentie bij bacteriën die van betekenis zijn voor dier en mens, tot onnodige of overdreven kosten voor de eigenaar en tot mogelijke bijwerkingen van de medicatie bij de hond of kat (Jessen et al., 2015). Het is daarom uiterst belangrijk om een correcte therapeutische aanpak te kiezen door (1) de aanwezigheid van een bacteriële UWI met zekerheid te bevestigen, (2) stil te staan bij de noodzaak van behandeling met een antibioticum en (3) het correcte antibioticum en de gewenste therapieduur te kiezen op basis van het type UWI en het antibiogram.

In 2019 zijn nieuwe richtlijnen van de "International Society for Companion Animal Infectious Diseases" (ISCAID) verschenen voor het diagnosticeren en behandelen van bacteriële UWI bij honden en katten (Weese et al., 2019). Hierin wordt duidelijk gemaakt dat in de originele richtlijnen uit 2011 (Weese et al., 2011) vaak een langere therapieduur geadviseerd werd dan vermoedelijk noodzakelijk is. De auteurs extrapoleren - bij gebrek aan gecontroleerde klinische studies bij kleine huisdieren - de meeste informatie uit de humane geneeskunde, waar UWI beduidend minder lang worden behandeld (Bonkat et al., 2018). Verder worden bacteriële UWI volgens deze nieuwe richtlijnen niet langer ingedeeld in 'gecompliceerde' en 'niet-gecompliceerde' UWI, maar in sporadische bacteriële cystitis, terugkerende bacteriële cystitis, pyelonefritis, prostatitis en SKB (Weese et al.,
2019). Elk van deze types UWI vereist dan ook een afzonderlijke aanpak. Ook kan er vaker worden overwogen om niet-steroïdale ontstekingsremmers ("nonsteroidal anti-inflammatory drugs" of NSAIDs) in te zetten om de klachten te verlichten in afwachting van de uitslag van een urinecultuur, naar analogie met de humane geneeskunde (Gáygor et al., 2015). Tot slot is het goed om bij elke diagnose van bacteriële UWI automatisch stil te staan bij het al dan niet aanwezig zijn van predisponerende factoren, om terugkerende infecties in de toekomst mogelijk te kunnen vermijden (Byron, 2019).

\section{DIAGNOSE EN PREDISPONERENDE FACTO- REN}

Voor alle vormen van bacteriële UWI geldt dat het vaststellen van een bacteriële UWI idealiter gebeurt op een urinestaal dat door middel van cystocentese wordt bekomen (Figuur 1). Alvorens het staal op te sturen voor cultuur, kan door de dierenarts zelf urinesediment worden bekeken om reeds een idee te hebben van het al dan niet aanwezig zijn van een bacteriële component. Het maken van een preparaat van urinesediment voor microscopisch onderzoek is heel eenvoudig (zie addendum). Op dit sediment wordt ofwel een dekglaasje aangebracht voor het bekijken van nat, ongekleurd sediment (met een x 40 objectief) (Figuur 2A) of de druppel krijgt de tijd om te drogen en wordt vervolgens gekleurd met een gemodificeerde wrightkleuring (bijvoorbeeld Diff-Quick) voor het bekijken van gekleurd sediment (met een x 40 en $\mathrm{x}$ 100 vergroting) (Figuur 2B en 2C). Het beste is om vijf tot tien microscopievelden te onderzoeken op de canwezigheid van leukocyten en bacteriën (Piech en Wycislo, 2019). Het correct interpreteren van microscopisch onderzoek van ongekleurd urinesediment vraagt wel wat oefening (Provoost et al., 2019). Daarnaast is de efficiëntie om zelf een bacteriële UWI te kunnen vaststellen hoger bij het gebruik van gedroogde en gekleurde stalen dan bij natte stalen, met
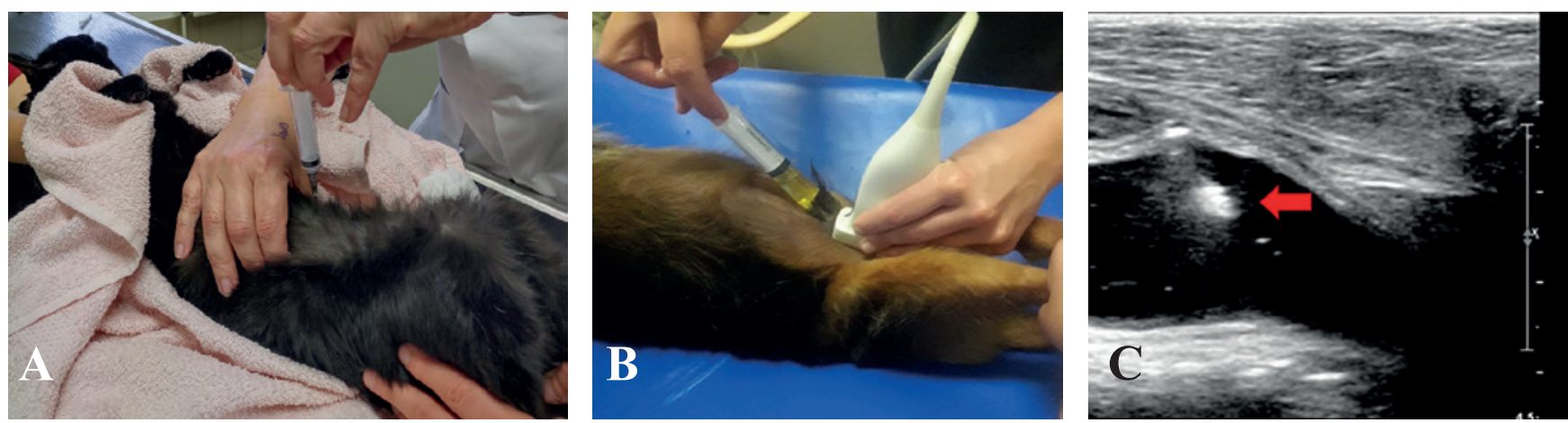

Figuur 1. A. Cystocentese bij een wakkere kat geïmmobiliseerd in dorsale decubitus door middel van een $5 \mathrm{~mL}$-spuit en 22G (zwarte) naald - een eenvoudige techniek bij dieren met een palpeerbare blaas. B. Echogeleide cystocentese bij een wakkere hond door middel van een 10mL-spuit en 22G- (zwarte) naald. C. Het echografisch beeld van de naald (rode pijl) in het blaaslumen (links in beeld = craniaal). 


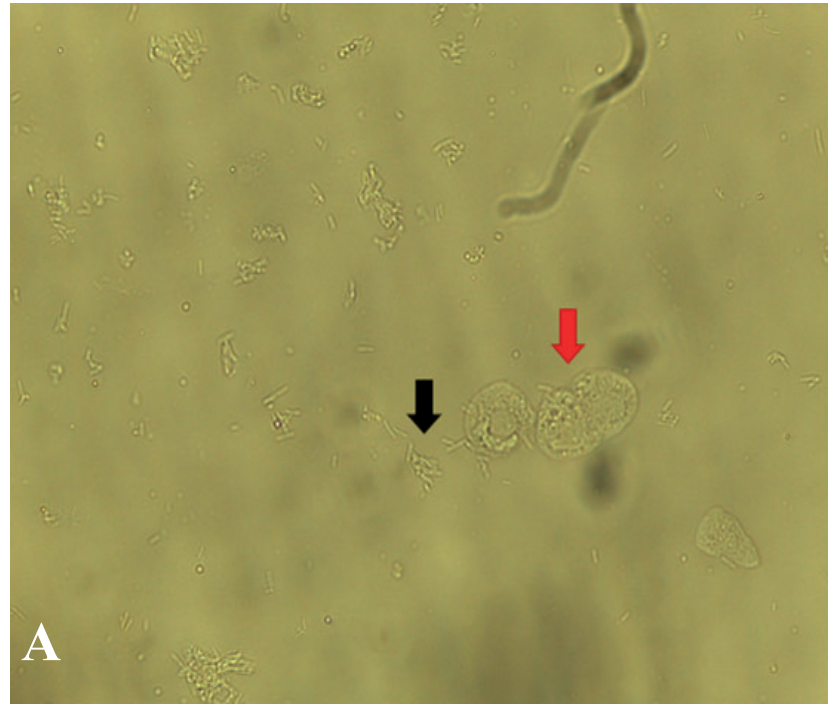

Figuur 2A. Ongekleurd urinesediment van een hond (x 40 vergroting). Er zijn enkele epitheelcellen zichtbaar (herkenbaar aan de ronde tot ovale kern, rode pijl) evenals talrijke bacteriën (kleinere structuren, onder andere ter hoogte van de zwarte pijl).

een sensitiviteit van $83 \%$ en specificiteit van $99 \%$ bij katten, indien een gekleurd sediment wordt bekeken door een getraind specialist (Swenson et al., 2011). In een studie bij honden bedroegen de sensitiviteit en specificiteit van een gekleurd urinesediment voor de detectie van bacteriurie en/of pyurie in het geval van een UWI respectievelijk $84 \%$ en $39 \%$ bij uitvoering door een praktijkdierenarts (Sørensen et al., 2018). Indien er een klinisch vermoeden bestaat van een UWI kan dus het beste alsnog een urinestaal worden opgestuurd voor cultuur, ook wanneer er geen microscopische aanwijzingen zijn voor infectie, omdat anders het risico bestaat dat een aanwezige infectie wordt gemist (Smee et al., 2013). Ook het omgekeerde is mogelijk, namelijk dat kleurstof- of andere artefacten verkeerdelijk worden aanzien voor bacteriën terwijl er geen sprake is van een UWI (Piech en Wycislo, 2019). Hoewel in de humane geneeskunde een teststrookje ("dipstick") wordt gebruikt voor het vaststellen van een UWI, is deze methode niet betrouwbaar voor de detectie van nitriet (bacteriën) en leukocytesterase (pyurie) in de urine van honden en katten (Smee et al., 2013; Byron, 2019). Zo testten in een studie van Paepe, et al. (2013) 98 van de 99 katten positief voor leukocytesterase, maar was van slechts één kat de urinecultuur positief.

Er bestaan systemen die door de dierenarts zelf kunnen gebruikt worden om een urinecultuur uit te voeren bij kleine huisdieren, maar deze zijn doorgaans minder sensitief dan systemen voor het uitvoeren van een cultuur in een professioneel labo en het duurt 24 uur vooraleer ze afgelezen kunnen worden, wat vaak niet sneller is dan bij een extern labo. Bijkomende nadelen zijn dat de bacteriesoort niet accuraat kan worden geïdentificeerd en dat er geen antibiogram wordt bepaald (Byron, 2019). Bovendien werd in een studie van Sørensen et al. (2018) aangetoond dat deze syste-

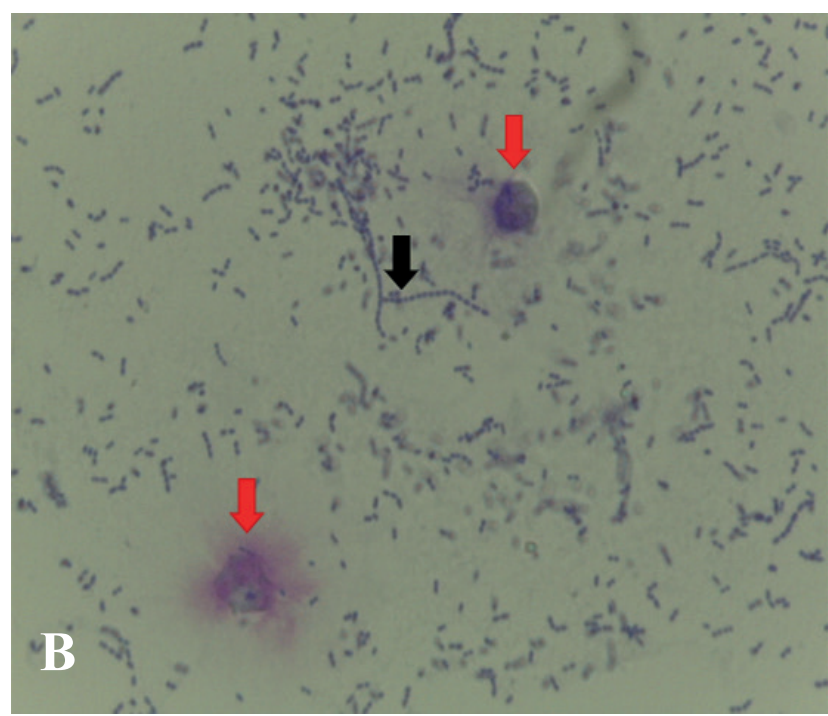

Figuur 2B. Gekleurd urinesediment (Diff-Quick) van een kat (x 40 vergroting). Er zijn twee neutrofielen zichtbaar (gedegenereerd, rode pijlen) evenals talrijke losliggende bacteriën (coccen - soms op een rijtje, zwarte pijl).

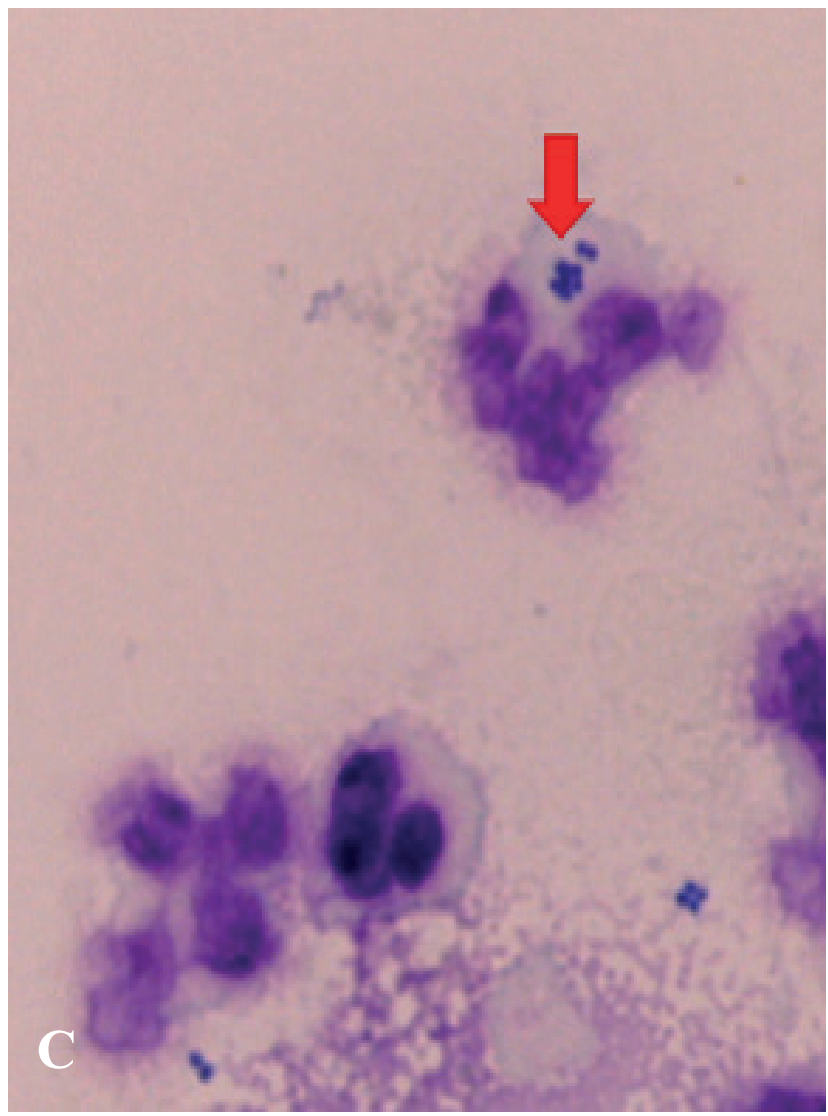

Figuur 2C. Gekleurd urinesediment (Diff-Quick) van dezelfde kat als in figuur 2B (x 100 vergroting). Er is een gedegenereerde neutrofiel met gefagocyteerde bacteriën (coccen) zichtbaar (intracellulair, rode pijl).

men een valspositief resultaat kunnen geven met een specificiteit van slechts $57 \%$.

Om de significantie van de groei na te gaan moet bij de interpretatie van het resultaat van een urinecul- 

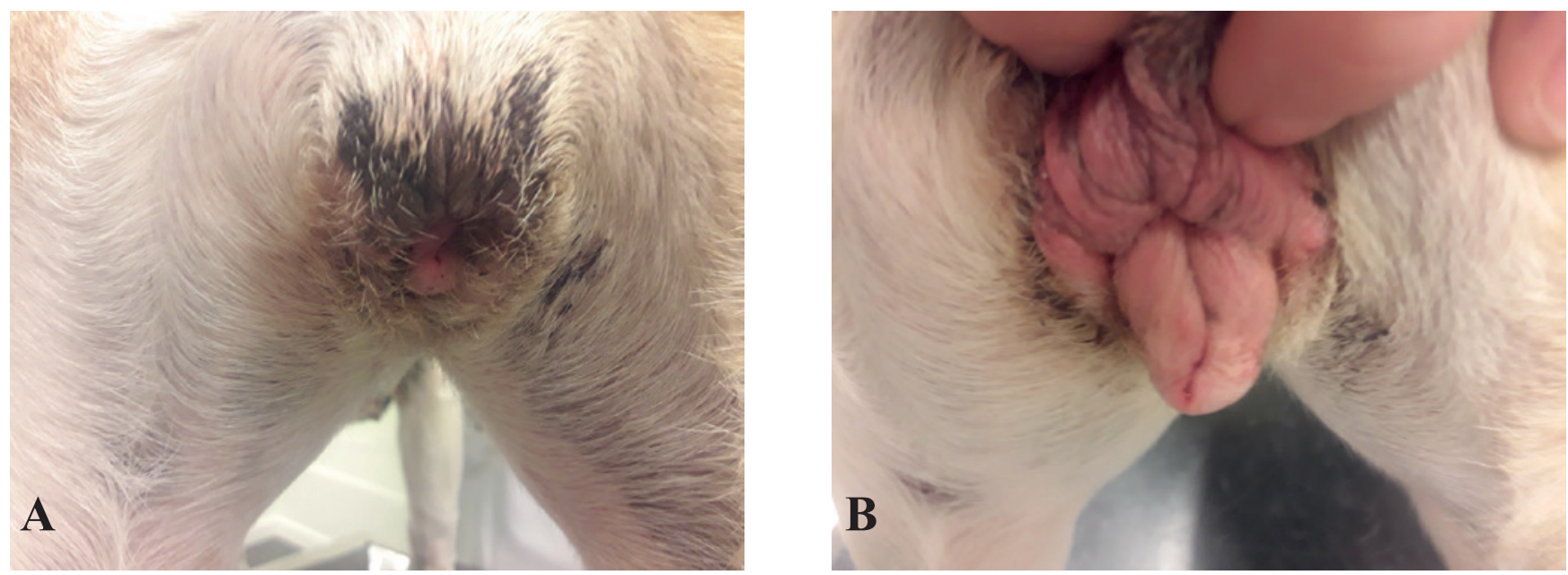

Figuur 3. A. Een teef met een zogenaamde "hooded" (bedekte) of "recessed" (verzonken) vulva, waarbij de opening quasi volledig wordt bedekt door een dorsale huidplooi. B. Dezelfde teef wanneer de huid strak naar boven wordt getrokken zoals bij chirurgische correctie door middel van vulvoplastie gebeurt.

tuur steeds het aantal organismen/ml (door het labo uitgedrukt in "colony forming units" of CFU/ml) dat in het staal aanwezig is, in acht worden genomen (Smee et al., 2013) (Tabel 1). Om contaminatie te vermijden blijft het belangrijk om stalen te nemen door middel van cystocentese en daarbij de huid vooraf te ontsmetten met alcohol en ervoor te zorgen dat spuit en naald voor, tijdens en na de cystocentese steriel gehanteerd worden. De spuit kan nadien het beste worden afgesloten met een steriel dopje en in de koelkast worden bewaard tot het naar het labo vertrekt, waar de urine idealiter binnen de 24 uur wordt geanalyseerd om valsnegatieve resultaten te vermijden (Patterson et al., 2016; Reppas en Foster, 2016).

Bij elk vermoeden van een bacteriële UWI kan er reeds van bij de anamenese het beste ook op worden gelet of er mogelijke predisponerende factoren aanwezig zijn, i. e. eventuele medicatie, de aanwezigheid van urinaire incontinentie; zeker bij gesteriliseerde teven, waarbij de prevalentie hiervan tussen de 3-20\% bedraagt (Timmermans et al., 2019) of klachten horend bij een endocriene of neurologische aandoening (Tabel 2). Vervolgens dient bij vrouwelijke dieren tijdens het lichamelijk onderzoek automatisch naar de conformatie van de vulva te worden gekeken (bijvoorbeeld het vaststellen van een "hooded" of bedekte vulva) (Figuur 3). Bij mannelijke dieren dient de pros- taat via rectaal onderzoek te worden geëvalueerd qua grootte, symmetrie en pijnlijkheid. Indien de cystocentese onder echografische begeleiding gebeurt, kan tegelijkertijd worden gelet op de aanwezigheid van eventuele blaasstenen, polypoïde cystitis of neoplasie van de blaaswand evenals een mogelijke prostaatpathologie, zoals benigne prostaathyperplasie met cystevorming, prostatitis of prostaatabcessen (Weese et al., 2019) (Figuur 4). Glucosurie predisponeert voor emfysemateuze cystitis en kan wijzen op een onderliggende ziekte als diabetes mellitus, zodat het uitvoeren van een dipsticktest steeds wordt aangeraden (Smee et al., 2013; Weese et al., 2019). Er wordt niet langer aangenomen dat slecht geconcentreerde urine op zich het risico op UWI verhoogt (Byron, 2019), maar een laag soortelijk gewicht kan wel een aanwijzing zijn voor een predisponerende aandoening voor een UWI of SKB, zoals chronische nierziekte of de ziekte van Cushing (Smee et al., 2013).

\section{THERAPIE}

\section{Sporadische bacteriële cystitis}

Er wordt gesproken van sporadische bacteriële cystitis indien een klinische UWI minder vaak op-

Tabel 1. Significante groei van bacteriën bij de cultuur van urine die werd verkregen via verschillende methoden (uit: Smee et al., 2013).

\begin{tabular}{lll}
\hline Methode & Honden $(\mathrm{CFU} / \mathrm{ml})$ & Katten $(\mathrm{CFU} / \mathrm{ml})$ \\
\hline Cystocentese & $\geq 1000$ & $\geq 1000$ \\
Katheterisatie & $\geq 10.000$ & $\geq 1000$ \\
Opvangen van "midstream" urine* & $\geq 100.000$ & $\geq 10.000$ \\
Manuele blaaslediging* & $\geq 100.000$ & $\geq 10.000$ \\
\hline
\end{tabular}

\footnotetext{
* Dergelijke stalen worden afgeraden voor urinecultuur.
} 

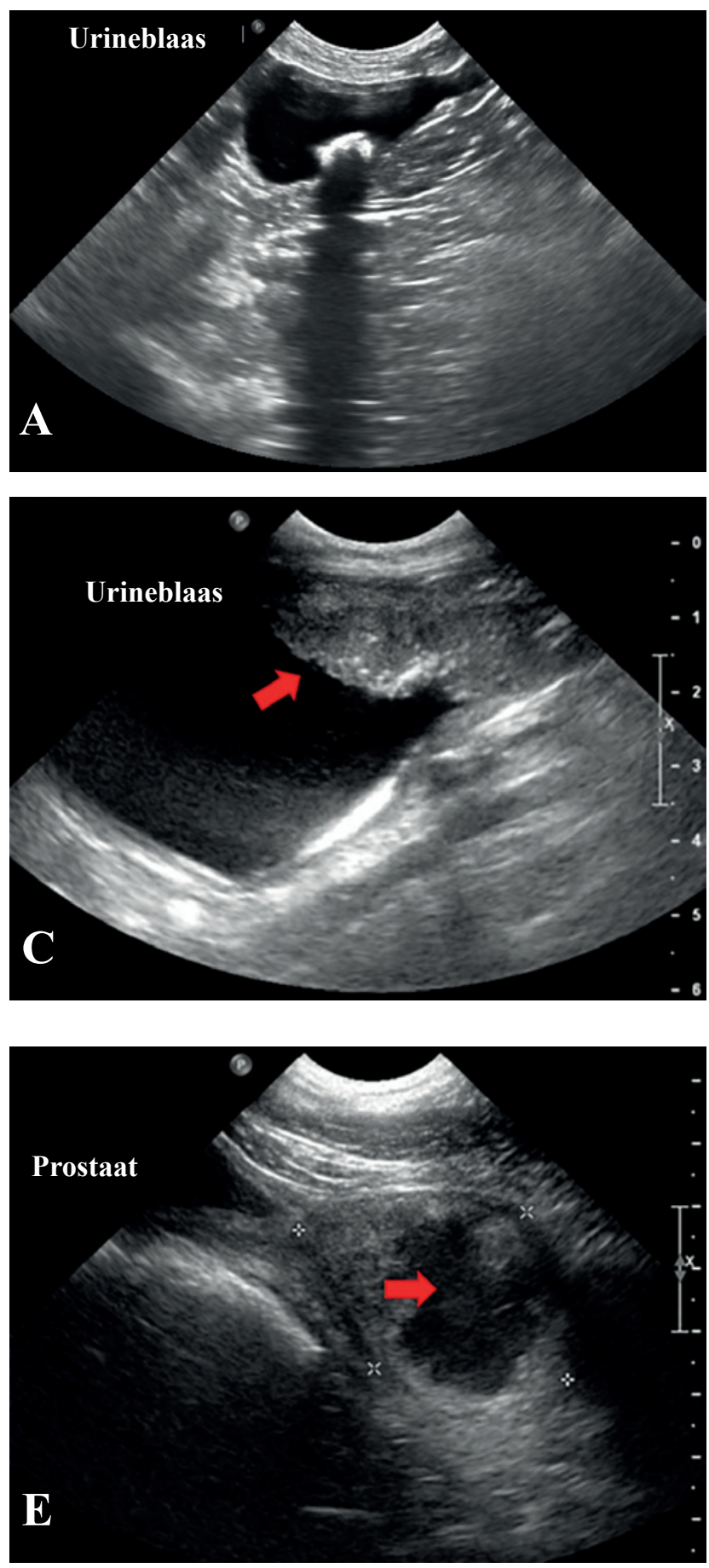

treedt dan drie keer per jaar of indien er minder dan twee episodes hebben plaatsgevonden in de laatste zes maanden (Bonkat et al., 2021; Weese et al., 2019). Bacteriële cystitis gaat gepaard met symptomen van de lagere-urinewegen en kan dus leiden tot pollakisurie, dysurie, strangurie en/of hematurie. Sporadische bacteriële cystitis komt vaak voor bij honden maar veel minder bij katten (Weese et al., 2019). Vrouwelijke honden en katten lopen een hoger risico op een bacteriële UWI dan reuen en katers (Byron, 2019). Desalniettemin is een bacteriële infectie slechts bij $38-65 \%$ van de honden de oorzaak van lagere-urinewegsymptomen (Sorensen et al., 2019). In studies uitgevoerd in Europa is bacteriële cystitis bij katten
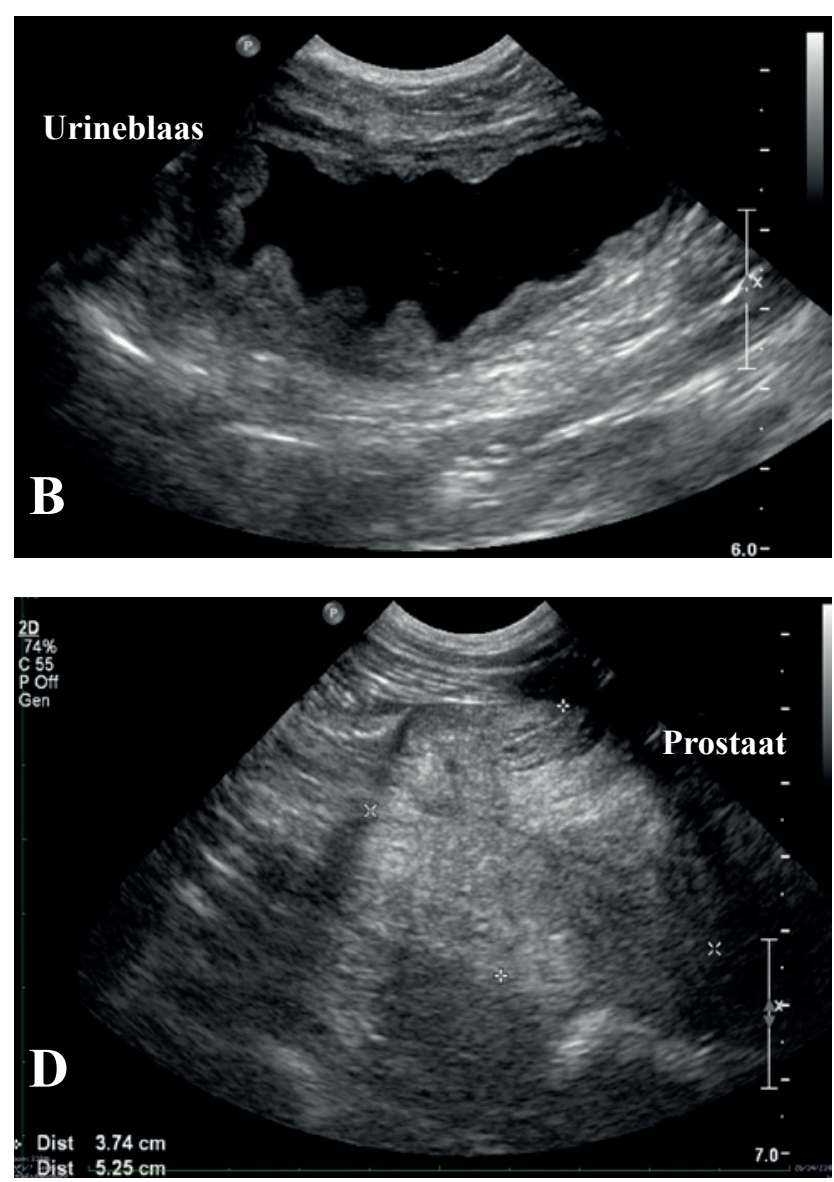

Figuur 4. Abnormaliteiten die kunnen worden opgemerkt ter hoogte van het urogenitale stelsel tijdens echogeleide cystocentese. A. Blaassteen met distale akoestische schaduw, B. Diffuus verdikte en onregelmatige blaaswand ten gevolge van polypoïde cystitis, $C$. Wekedelenmassa (overgangscelcarcinoom) ter hoogte van het trigonum (rode pijl), D. grote, hyperechogene en heterogene prostaat ten gevolge van benigne prostaathyperplasie en prostatitis, E. met hypoechogene inhoud gevulde holte in prostaat ten gevolge van een prostaatabces (rode pijl).

met lagere-urinewegklachten zelfs maar in 8-25\% van de gevallen de oorzaak. Een frequentere oorzaak bij katten is feliene idiopathische cystitis, zeker op jonge leeftijd. Het is bijgevolg uiterst belangrijk om een correcte diagnose te stellen en niet onnodig antibiotica in te zetten (Sævik et al., 2011). Andere mogelijke oorzaken van symptomen van de lagere-urinewegen zijn urolithiase en eventueel neoplasie of granulomateuze uretritis (Sævik et al., 2011; Smee et al., 2013; Weese et al., 2019).

De diagnose van bacteriële cystitis wordt idealiter bevestigd aan de hand van een urinecultuur op een staal genomen via cystocentese. Bij katten dient steeds het resultaat van deze urinecultuur te worden afgewacht alvorens een antibioticumtherapie op te starten, aangezien de meerderheid van de katten met lagereurinewegklachten geen bacteriële cystitis heeft. Bij 
Tabel 2. Aandoeningen die predisponeren tot bacteriële urineweginfecties (of subklinische bacteriurie) bij honden en katten (uit: Weese et al., 2019).

\author{
Immunosuppressieve medicatie: o.a. prednisolone, cyclosporine \\ Endocrinopathie: ziekte van Cushing, diabetes mellitus, hyperthyroïdie \\ Chronische nierziekte \\ Obesitas \\ Abnormale conformatie van de vulva \\ Urinaire incontinentie: o.a. ectopische ureter, resterende paramesonefrische membraan \\ Neurologische problemen die leiden tot urinaire retentie \\ Prostaataandoeningen: o.a. benigne prostaathyperplasie \\ Neoplasie blaaswand: o.a. overgangscelcarcinoom \\ Urolithiase \\ Rectale fistel
}

honden kan bij een sterk vermoeden van bacteriële cystitis (door bijvoorbeeld intracellulaire bacteriën in leukocyten waargenomen bij microscopisch onderzoek van het urinesediment) reeds met een empirische antibioticumbehandeling worden gestart in afwachting van de uitslag van een urinecultuur (Figuur 2C). In de literatuur wordt vermeld dat de urinecultuur niet noodzakelijk uitgevoerd dient te worden bij honden met sporadische bacteriële cystitis, vooral wanneer ze eerder slechts beperkt met antibiotica werden behandeld (Weese et al., 2019). De auteurs zijn echter van mening dat dit een minder ideale aanpak is. Indien er voor empirische therapie wordt gekozen en indien uit het antibiogram blijkt dat de aanwezige bacterie resistent is tegen de opgestarte antibioticumbehandeling, dan dient de medicatie te worden aangepast tenzij er in de tussentijd reeds een goede klinische respons is opgetreden (Weese et al., 2019).

In de humane geneeskunde werd bij vrouwelijke patiënten aangetoond dat de toediening van NSAIDs gedurende drie dagen zonder bijkomende antibiotica effectief kan zijn voor de behandeling van bacteriële cystitis en tot klinisch herstel leidt in twee derden van de gevallen (Gáygor et al., 2015). Het valt daarom te overwegen om enkel NSAIDs toe te dienen gedurende enkele dagen bij dieren die enkel cystitisklachten vertonen. Worden de klachten niet beter, kan alsnog een antibioticumbehandeling worden opgestart zodra het antibiogram beschikbaar is (Weese et al., 2019).

Het eerstekeuzeantibioticum is amoxicilline of, indien dit niet beschikbaar is, amoxicilline-clavulaanzuur (Tabel 3). Een ander eerstekeuzeantibioticum is een trimethoprim-sulfonamidepreparaat. Indien dit laatste antibioticum langdurig wordt toegediend, gaat dit gepaard met verschillende mogelijke bijwerkingen. Bij een korte behandelingsduur van drie tot vijf dagen (die nu wordt geadviseerd bij sporadische bacteriële cystitis) zijn deze neveneffecten echter onwaarschijnlijk (Weese et al., 2019).

Indien de klachten niet verbeteren binnen de 48 uur na de start van de antibioticumtherapie, dient verder onderzoek te worden gedaan. Indien nog niet gebeurd, dient een urinecultuur uitgevoerd te worden, alsook een echografie van de blaas om andere oorzaken voor de lagere-urinewegklachten en/of complicerende factoren, zoals urolithiase, poliepen of neoplasie, op te sporen. Een standaard controle-urinecultuur na het einde van de antibioticumbehandeling is niet noodzakelijk indien de klinische klachten verdwenen zijn (Weese et al., 2019).

\section{Terugkerende bacteriële cystitis}

Indien een hond of kat drie of meer episodes van bacteriële cystitis doormaakt in twaalf maanden tijd, of wanneer een nieuwe bacteriële cystitis optreedt binnen de zes maanden na de vorige, spreekt men van terugkerende bacteriële cystitis (Bonkat et al., 2021; Byron, 2019). Dit kan het gevolg zijn van een herval met dezelfde kiem, een herinfectie met een andere kiem, of het persisteren van de oorspronkelijke kiem, bijvoorbeeld in de diepere lagen van de blaaswand (Olin en Barges, 2015; Byron, 2019).

Bij het vermoeden van terugkerende bacteriële cystitis dient steeds een urinecultuur te worden uitgevoerd. In afwachting van het resultaat van de urinecultuur kan ook hier worden geopteerd om een behandeling met NSAIDs in te zetten (Weese et al., 2019).

Betreft het een andere kiem dan bij de vorige episode, dan moet worden onderzocht of er een mogelijke predisponerende aandoening aanwezig is (Tabel 2 ). Een dergelijke onderliggende oorzaak is niet altijd corrigeerbaar, maar kan in sommige gevallen wel worden aangepakt (zoals vulvoplastie voor een "hooded" vulva, medicamenteuze behandeling van diabetes mellitus of urinaire incontinentie) om zo recidieven in de toekomst te vermijden. Gaat het om een herval met of persistentie van dezelfde kiem, dan dient te worden bekeken of de vorige keer het correcte antibioticum en de correcte dosis/frequentie werden gekozen. Bovendien kan bij de eigenaar worden gepolst naar diens therapietrouw. Indien er geen onregelmatigheden worden opgemerkt, dan dient ook in deze gevallen op zoek te worden gegaan naar predisponerende factoren bij het dier zelf (Weese et al., 2019).

Hoewel vroeger werd aangeraden om bij terugke- 
rende bacteriële cystitis vier weken lang te behandelen, is dit niet langer het geval, zelfs niet bij dieren met een onderliggende aandoening zoals diabetes mellitus. Het huidige advies is om net als bij een eerste episode gedurende drie tot vijf dagen te behandelen met een eerstekeuzeantibioticum, zeker indien het een herinfectie met een andere kiem betreft. Een langere therapieduur van zeven tot veertien dagen kan worden overwogen in het geval van persisterende infecties of een herval, of wanneer de aanwezigheid wordt vermoed van factoren die het effect van antibiotica verminderen, zoals invasie van de blaaswand door E. coli. In dit laatste geval is amoxicilline(-clavulaanzuur) overigens geen geschikte keuze omwille van de slechte weefselpenetratie (Weese et al., 2019), waardoor een fluoroquinolone een betere optie is bij

Tabel 3. Samenvatting van de eerstekeuzeantibioticumtherapie voor UWI bij kleine huisdieren (naar: Olin en Bartges, 2015; Weese et al., 2019).

\begin{tabular}{|c|c|c|c|}
\hline Type UWI & Antibioticum & Duur (d) & Opmerkingen \\
\hline \multirow[t]{4}{*}{ Sporadische cystitis } & $\begin{array}{l}1^{\mathrm{e}} \text { keuze: amoxicilline } 11-15 \mathrm{mg} / \mathrm{kg} \\
\text { q8-12u PO } \\
\text { of } \\
\text { trimethoprim-sulfa (TMS) } 15-30 \mathrm{mg} / \mathrm{kg} \\
\text { q12u PO }\end{array}$ & $3-5$ & $\begin{array}{l}\text { Als amoxicilline niet beschikbaar: } \\
\text { amoxicilline-clavulaanzuur } 12,5-25 \mathrm{mg} / \mathrm{kg} \\
\text { q12u PO (dosis = gebaseerd op de } \\
\text { concentratie van beide bestanddelen samen). } \\
\text { Dosis TMS = gebaseerd op de totale } \\
\text { concentratie van beide bestanddelen samen. }\end{array}$ \\
\hline & $\begin{array}{l}\text { 2e keuze: nitrofurantoïne } 4,4-5 \mathrm{mg} / \mathrm{kg} \\
\text { q8u PO }\end{array}$ & $3-5$ & $\begin{array}{l}2^{\mathrm{e}} \text { keuze: enkel indien organisme niet gevoelig } \\
\text { aan amoxicilline en TMS! }\end{array}$ \\
\hline & of enrofloxacine 5 (tot 10 bij de hond) & & Enrofloxacine kat: risico op retinadegeneratie \\
\hline & $\begin{array}{l}\mathrm{mg} / \mathrm{kg} \mathrm{q} 24 \mathrm{u} \text { PU } \\
\text { of cefalexine } 12-25 \mathrm{mg} / \mathrm{kg} \mathrm{q} 12 \mathrm{u} \mathrm{PO}\end{array}$ & & $\begin{array}{l}\text { b1j hogere dosissen }(>>\mathrm{mg} / \mathrm{kg}) \text {. } \\
\text { Cefalexine: eerstegeneratiecefalosporine. }\end{array}$ \\
\hline \multirow[t]{2}{*}{ Terugkerende cystitis } & $\begin{array}{l}1^{\mathrm{e}} \text { keuze: amoxicilline } 11-15 \mathrm{mg} / \mathrm{kg} \\
\text { q8-12u PO } \\
\text { of } \\
\text { trimethoprim-sulfa (TMS) } 15-30 \mathrm{mg} / \mathrm{kg} \\
\text { q12u PO }\end{array}$ & $3-5$ & $\begin{array}{l}\text { Zie sporadische cystitis. Bij E. coli infectie } \\
\text { met invasie van de blaaswand, leidend } \\
\text { tot persistentie/herval, is amoxicilline } \\
\text { (+/- clavulaanzuur) niet geschikt. } \\
\text { Dosis TMS: gebaseerd op de totale concentratie } \\
\text { van beide bestanddelen samen. }\end{array}$ \\
\hline & $\begin{array}{l}2^{\mathrm{e}} \text { keuze: nitrofurantoïne of } \\
\text { enrofloxacine of cefalexine }\end{array}$ & $3-5$ & Zie sporadische cystitis. \\
\hline \multirow[t]{2}{*}{ Pyelonefritis } & $\begin{array}{l}1^{\mathrm{e}} \text { keuze: enrofloxacine } 10(-20) \mathrm{mg} / \mathrm{kg} \\
\text { q24u PO / IV (hond) } \\
\text { of marbofloxacine } 2,7-5,5 \mathrm{mg} / \mathrm{kg} \\
\text { q24u PO / IV (kat) }\end{array}$ & $10-14$ & $\begin{array}{l}\text { Enrofloxacine kat: risico op retinadegeneratie } \\
\text { bij hogere dosissen ( }>5 \mathrm{mg} / \mathrm{kg} \text { ), daarom is } \\
\text { marbofloxacine een betere keuze voor } \\
\text { pyelonefritis bij de kat. }\end{array}$ \\
\hline & $\begin{array}{l}\text { 2e keuze: cefovecine } 8 \mathrm{mg} / \mathrm{kg} \text { q14 } \\
\text { (hond)-21(kat) dagen SC }\end{array}$ & & $\begin{array}{l}\text { Cefovecine: derdegeneratiecefalosporine. Exacte } \\
\text { duur van het effect niet te voorspellen. } \\
\text { Enkel gebruiken indien orale medicatie } \\
\text { ingeven onmogelijk is! }\end{array}$ \\
\hline \multirow[t]{2}{*}{ Prostatitis (hond) * } & $\begin{array}{l}\text { 1e keuze: enrofloxacine } 10 \mathrm{mg} / \mathrm{kg} \\
\text { q } 24 \mathrm{u} \text { PO / IV } \\
\text { of } \\
\text { trimethoprim-sulfa (TMS) } 15-30 \mathrm{mg} / \mathrm{kg} \\
\text { q12u PO / SC }\end{array}$ & $28-42$ & $\begin{array}{l}\text { Zo snel mogelijk castreren. Indien } \\
\text { prostaatabces aanwezig: abces ook draineren } \\
\text { dmv echogeleide percutane aspiratie of bij } \\
\text { recidieven dmv chirurgische drainage. } \\
\text { TMS: immuungemedieerde reacties mogelijk } \\
\text { bij gebruik langer dan } 7 \text { dagen.** }\end{array}$ \\
\hline & $\begin{array}{l}\text { 2e keuze: clindamycine } 11-15 \mathrm{mg} / \mathrm{kg} \\
\text { q12u PO / IV }\end{array}$ & $28-42$ & $\begin{array}{l}\text { Clindamycine: penetreert de bloed-prostaas } \\
\text { barrière. Niet effectief tegen gramnegatieve } \\
\text { bacteriën, daarom enkel inzetten indien } \\
\text { geschikt volgens cultuur en antibiogram. }\end{array}$ \\
\hline Subklinische bacteriurie & Geen! & - & $\begin{array}{l}\text { Antibioticumtherapie niet geïndiceerd in deze } \\
\text { gevallen, ook niet wanneer comorbiditeiten } \\
\text { aanwezig zijn (bv. diabetes mellitus). }\end{array}$ \\
\hline
\end{tabular}

* Intacte, mannelijke honden: indien positieve urinecultuur en lagere-urinewegklachten, maar geen tekenen van prostatitis = behandeling als bij sporadische cystitis.

** Mogelijke immungemedieerde en idiosyncratische bijwerkingen bij een gebruik $>7$ dagen zijn o.a. keratoconjunctivitis sicca, huidletsels, hepatopathie, immuungemedieerde polyartritis en hemolytische anemie. Bij honden dient vóór de start een Schirmer-teartest uitgevoerd te worden en deze dient tijdens therapie met TMS periodiek te worden herhaald. 
dergelijke E. coli-infecties (González et al., 2020). Rechtstreekse toediening van antibiotica in de blaas wordt afgeraden (Weese et al., 2019).

Vroeger werd aangeraden om de urinecultuur bij een dergelijke UWI tijdens de antibioticumtherapie te herhalen. Het nut hiervan is echter onduidelijk, zeker tijdens een korte antibioticumtoediening gedurende drie tot vijf dagen. Wel wordt geadviseerd om bij elk dier met terugkerende UWI de urinecultuur te herhalen vijf tot zeven dagen na het einde van de antibioticumbehandeling, op het moment dat de klinische klachten (nog) onder controle zijn. Deze aanpak kan in de toekomst helpen bepalen of het om een herval dan wel om een persisterende infectie gaat, indien de klachten zich opnieuw zouden voordoen. Zolang er geen cystitisklachten meer aanwezig zijn, wordt verdere therapie niet aangeraden, ook niet indien de cultuur vijf tot zeven dagen na het einde van de behandeling positief zou zijn. Het doel van de behandeling is eliminatie van klinische klachten, maar niet per se eliminatie van alle aanwezige bacteriën (Weese et al., 2019).

Voor de preventie van terugkerende UWI werd vroeger soms profylactische antibioticumtherapie toegepast (bijvoorbeeld nitrofurantoïne q24u 's avonds laat bij honden), maar studies in de humane geneeskunde hebben bij vrouwelijke patiënten uitgewezen dat een dergelijke aanpak antibioticumresistentie in de hand werkt (Fisher et al., 2018). Bovendien is het nut van profylactische antibiotica voor het verhinderen van terugkerende cystitis bij kleine huisdieren niet bewezen en kan de medicatie bijwerkingen met zich meebrengen. Deze strategie wordt dus niet aangeraden voor honden en katten (Weese et al., 2019).

\section{Bovenste-UWI (pyelonefritis)}

Bij pyelonefritis is er sprake van een infectie van het nierbekken en -parenchym, ofwel door een opgeklommen lagere-UWI (waarbij vooraf niet altijd cystitisklachten worden opgemerkt), ofwel door de verspreiding van bacteriën via de bloedbaan (van Dongen, 2016; Weese et al., 2019).

De diagnose wordt gesteld aan de hand van een positieve urinecultuur in combinatie met bijhorende klinische klachten, zoals koorts, lethargie of pijn bij palpatie van de nieren. Bij bloedonderzoek kunnen azotemie en/of neutrofilie aanwezig zijn en er kunnen cilinders zichtbaar zijn bij het sedimentonderzoek van de urine (Weese et al., 2019) (Figuur 5). Tijdens echografie van de nieren kan nierbekkendilatatie vastgesteld worden, maar dit is niet specifiek voor pyelonefritis (D'Anjou et al., 2011). Wanneer er een sterk vermoeden van pyelonefritis bestaat, maar de urinecultuur verkregen via cystocentese (mogelijk vals) negatief is, kan door middel van pyelocentese een staal rechtstreeks uit het nierbekken worden genomen. Bij een dier met koorts kan een bloedcultuur ook een optie zijn om de oorzakelijke kiem op te sporen (Weese

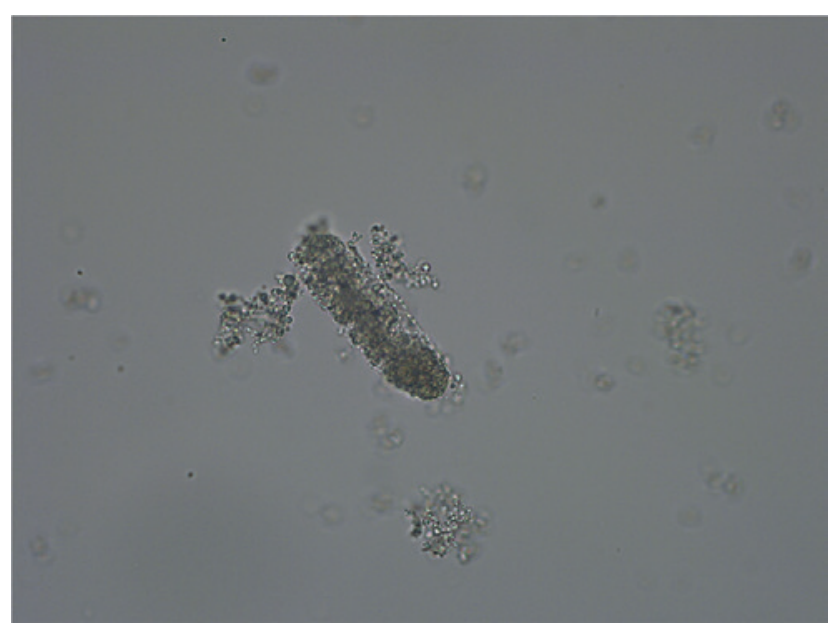

Figuur 5. Ongekleurd urinesediment van een hond waarin een granulaire cilinder zichtbaar is met parallelle randen en een goudbruine kleur (x 40 vergroting). Dergelijke cilinders bevatten gedegenereerde cellen en mucoproteïnen (uit: Piech en Wycislo, 2019).

et al., 2019). Tot slot kan tevens overwogen worden om diagnostiek voor leptospirose uit te voeren (door middel van serologie en PCR van urine of bloed) bij honden met nefritis waarbij de urinecultuur negatief is (Sykes et al., 2011).

Het is belangrijk om op het aanvraagformulier voor de urinecultuur steeds duidelijk aan te geven dat het een vermoeden van pyelonefritis betreft, zodat het antibiogram kan gebaseerd worden op de concentraties die de antibiotica in de weefsels bereiken in plaats van op de urinaire concentraties (Weese et al., 2019).

Bij een vermoeden van pyelonefritis dient na de bemonstering meteen antibioticumtherapie te worden opgestart, nog vóór het resultaat van de urinecultuur bekend is, aangezien dit anders kan leiden tot snelle en ernstige nierschade. Een eerstekeuzeantibioticum is een fluoroquinolone (Olin en Bartges, 2015). Volgens de meest recente richtlijnen is een cefalosporine van de derde generatie eveneens een mogelijk eerstekeuzeantibioticum (Weese et al., 2019), maar het enige cefalosporine van de derde generatie dat momenteel beschikbaar is voor het gebruik bij kleine huisdieren is cefovecine onder de vorm van een injectiepreparaat dat 14 (bij de hond) tot mogelijk 21 (bij de kat) dagen werkzaam is (Convenia ${ }^{\circledR}$, Zoetis, België). Hier is echter voorzichtigheid geboden gezien de lange werkingsduur (waardoor onmiddellijke stopzetting naar aanleiding van het resultaat van het antibiogram bijvoorbeeld niet mogelijk is) en de niet exact voorspelbare werkingsduur (die soms te kort en soms te lang kan zijn). Daarom geniet dagelijkse orale therapie met een fluoroquinolone de voorkeur, met initiële dagelijkse intraveneuze toediening in het geval van een slechte eetlust (Olin en Barges, 2015). Ook intraveneuze vloeistoftherapie kan aanvankelijk nodig zijn (van Dongen, 2016), evenals ondersteunende medicatie (pijnstilling onder de vorm van een opiaat en/of een anti-emeticum zoals maropitant). 
Indien er binnen de 72 uur na de start van de antibioticumtherapie geen verbetering optreedt van de klinische toestand en bloedwaarden (neutrofielen, azotemie), en als de kiem volgens het antibiogram wel gevoelig is voor het ingestelde antibioticum en de eigenaar de medicatie correct toedient, dient gecontroleerd te worden of er nog andere factoren aanwezig zijn (bijvoorbeeld ureterolieten of neoplasie) die de klachten (mede)veroorzaken (Weese et al., 2019).

Voorheen werd voor pyelonefritis een antibioticumtherapie van vier tot zes weken aangeraden (Weese et al., 2011). In de humane geneeskunde wordt echter een behandeling van zeven tot veertien dagen geadviseerd en er is geen reden om aan te nemen dat een langere behandelingsduur noodzakelijk zou zijn bij kleine huisdieren. De ISCAID-richtlijnen werden daarom aangepast naar tien tot veertien dagen (Weese et al., 2019).

Hier wordt evenmin een standaard controle-urinecultuur tijdens de antibioticumtherapie aangeraden, maar wel een controle van de urinecultuur en serumcreatinineconcentratie zeven tot veertien dagen na het einde van de antibioticumkuur. Ook hier geldt dat een positieve urinecultuur alleen, zonder de aanwezigheid van klinische klachten of azotemie, geen reden is om opnieuw een antibioticumbehandeling op te starten. De resultaten van de urinecultuur kunnen wel worden gebruikt bij een eventuele volgende klinische episode. Op dat moment kan namelijk een empirische antibioticumtherapie worden opgestart gebaseerd op de vorige urinecultuur, in afwachting van de resultaten van een nieuwe urinecultuur en antibiogram (Weese et al., 2019).

\section{Prostatitis}

Bij mannelijke, intacte honden met klachten door een lagere-UWI maar zonder aanwijzingen voor prostatitis dient dezelfde behandeling te worden ingesteld als bij 'gewone' cystitis (zie sporadische bacteriële cystitis), hoewel dit vroeger soms anders werd geadviseerd (Weese et al., 2019). Indien daarentegen het vermoeden van bacteriële prostatitis bestaat, kan het beste een antibioticum worden gekozen dat een goede weefselconcentratie bereikt in de prostaat. Indicaties hiervoor zijn wanneer bovenop lagere-urinewegklachten ook symptomen als lethargie, anorexie en/ of braken evenals koorts, neutrofilie en een pijnlijke prostaat bij rectale palpatie worden vastgesteld (in het geval van acute prostatitis) en/of een positieve urinecultuur in combinatie met echografische prostaatveranderingen (bij zowel acute als chronische prostatitis) (Kutzler, 2016). Wanneer prostatitis sterk wordt vermoed op basis van het klinische en echografische beeld, maar de urinecultuur negatief blijkt, kan geprobeerd worden om prostaatvocht te bekomen voor cultuur (Weese et al., 2019). Hiervoor kan 1. de derde fractie van het ejaculaat worden verzameld voor cultuur (eventueel met behulp van sedatie en/of analge- sie, indien de hond een erg pijnlijke prostaat heeft), 2. een zogenaamde "prostatic wash" worden uitgevoerd met behulp van een urinesonde in de urethra, 3. een echogeleide aspiratie van prostaatvocht uit een prostaatcyste of -abces worden uitgevoerd of 4. zelfs een prostaatbiopt worden genomen (Olin en Bartges, 2015; Weese et al., 2019). Wanneer het een reu betreft die voor de fok wordt gebruikt, moet ook een serologische test voor Brucella canis worden uitgevoerd (Weese et al., 2019).

Hoewel de bloed-prostaatbarrière mogelijk minder effectief is bij acute prostatitis, valt dit onmogelijk te voorspellen en kan de penetratie van bepaalde antibiotica in de prostaat dus nog steeds beperkt zijn. Fluoroquinolones en trimethoprim dringen wel steeds goed door tot in de prostaat en zijn dus eerstekeuzeantibiotica. Bij chlooramfenicol bedraagt de weefselconcentratie in de prostaat slechts $60 \%$ van de plasmaconcentratie, zodat therapeutische concentraties vermoedelijk niet worden bereikt. Bij doxycycline wordt zelfs maar een weefselconcentratie van $<20 \%$ van de plasmaconcentratie bereikt, zodat dit antibioticum zeker niet wordt aangeraden (Weese et al., 2019).

Chirurgische castratie moet steeds worden geadviseerd aan de eigenaar en kan het beste zo snel mogelijk gebeuren, maar niet voor er reeds vijf tot zeven dagen een antibioticum werd toegediend (Kutzler, 2016). Indien de eigenaar niet opteert voor chirurgische castratie en/of in afwachting van de geplande ingreep, kan er voor medicamenteuze therapie met antiandrogenen (finasteride, osaterone acetaat) of een GnRH-agonist (deslorelin) worden gekozen (Nizanski et al., 2014; Olin en Barges, 2015; Weese et al., 2019).

Voorheen werd een antibioticumtherapie van vier tot twaalf weken aangeraden (Nizanski et al., 2014); tegenwoordig is het advies om vier weken te behandelen in het geval van acute prostatitis en vier tot zes weken bij chronische prostatitis, al zou ook een kortere duur reeds kunnen volstaan bij gelijktijdige castratie en snelle klinische verbetering (Weese et al., 2019). Indien er sprake is van één of meerdere abcessen, dienen deze te worden gedraineerd aan het begin van de antibioticumtherapie. Dit kan echogeleid percutaan gebeuren (aspiratie), waarbij $>50 \%$ kans bestaat op herval, of chirurgisch (omentalisatie) (Kutzler, 2016).

Een controlecultuur van de urine of prostaatvocht tijdens therapie wordt niet aangeraden. Het opvolgen van de klinische respons en de normalisatie van de prostaatgrootte en -architectuur op echografie is de belangrijkste indicator voor het effect van de therapie, die soms langer dan vier tot zes weken dient te worden aangehouden. Een urinecultuur na de behandeling wordt evenmin geadviseerd indien er geen klinische klachten meer zijn (Weese et al., 2019).

\section{Subklinische bacteriurie}

De definitie van subklinische bacteriurie (SKB) is de aanwezigheid van bacteriën in de urine (aange- 
toond aan de hand van een positieve cultuur) zonder dat er sprake is van bijhorende klinische klachten (Weese et al., 2019). Bij gezonde honden blijkt de frequentie van SKB te variëren tussen 2,1-12\% (Marynissen et al., 2017; Wan et al., 2014; Weese et al., 2019 ) en dit stijgt tot $15-74 \%$ bij honden met diabetes mellitus, obesitas, acute discus hernia, chronische paralyse, cyclosporine- of glucocorticoïdentherapie en bij puppy's met parvovirose (Weese et al., 2019). Bij gezonde katten wordt een gelijkaardige prevalentie gemeld als bij gezonde honden, met SKB bij 1-13\% van de onderzochte dieren (Paepe et al., 2013; White et al., 2016).

Voorheen werd aangeraden om meermaals per jaar een urinecultuur uit te voeren bij dieren met immunosuppressie door ziekte (bijvoorbeeld bij de ziekte van Cushing) of door medicatie, en soms wordt een urinecultuur uitgevoerd als deel van een gezondheidsscreening, bijvoorbeeld bij oudere dieren. Bij dieren met een positieve urinecultuur maar zonder bijhorende klinische klachten was het voorheen niet duidelijk hoe dit het beste kon worden aangepakt. In de nieuwe ISCAID-richtlijnen wordt echter gesteld dat er bij een gebrek aan klinische symptomen van een UWI geen antibioticumbehandeling dient te worden opgestart. Dit advies geldt ook indien er bij het dier in kwestie sprake is van immunosuppressie, of indien vermoed wordt dat het dier geen lagere-urinewegklachten kan vertonen omwille van een neurologische aandoening (Weese et al., 2019). Studies hebben namelijk aangetoond dat onbehandelde SKB niet leidt tot een verhoogd risico op het ontstaan van klinische cystitis bij teven (Wan et al., 2014), noch tot koorts of een verminderd overlevingspercentage bij verlamde honden (Baigi et al., 2017) of een verminderde overlevingstijd bij oudere katten (White et al., 2016).

De beslissing om al dan niet een antibioticatherapie op te starten hangt evenmin af van de aan- of afwezigheid van pyurie of van het aantal bacteriën (in CFU/ml) dat in de cultuur wordt vastgesteld, maar enkel en alleen van het klinische beeld, i. e. klachten van de lagere-urinewegen of mogelijke pyelonefritistekenen, zoals koorts of acute azotemie (Weese et al., 2019). In de humane geneeskunde werd aangetoond dat de behandeling van SKB in de meeste gevallen niet nodig is en zelfs schadelijk kan zijn (Köves et al., 2017b). Antibioticumtherapie bij SKB leidt bij vrouwelijke patiënten zelfs tot een hoger risico op bacteriurie bij een controle na zes en twaalf maanden met bovendien een hoger risico op antibioticumresistentie (Cai et al., 2012; Cai et al., 2015). In de humane geneeskunde wordt behandeling van SKB enkel nog aangeraden bij zwangere vrouwen en bij patiënten die urologische chirurgie zullen ondergaan (Köves et al., 2017b).

Het routinematig uitvoeren van een urinecultuur als screening bij dieren die een verhoogd risico hebben op SKB wordt dus niet langer aangeraden en een controle-urinecultuur bij dieren, waarbij eerder SKB werd vastgesteld, is evenmin nodig zolang klinische klachten uitblijven (Weese et al., 2019).

\section{Urinesondes}

Een urinesonde in de urethra vormt een rechtstreekse verbindingsweg tussen de directe omgeving en de blaas, waardoor er steeds een risico bestaat op de ontwikkeling van bacteriurie of eventueel bacteriële cystitis (Weese et al., 2019). Het risico stijgt bij langdurige katheterisatie (Köves et al., 2017a; Weese et al., 2019). De prevalentie van bacteriurie bij gesondeerde honden en katten varieert van $10-55 \%$, waarbij het in de meerderheid van de gevallen vermoedelijk om SKB gaat (Weese et al., 2019).

Aandachtspunten ter preventie zijn een goede (aseptische) plaatsing en onderhoud van de urinesonde, het gebruiken van een gesloten opvangsysteem, regelmatige visuele controle voor contaminatie met feces of openingen/gaatjes in het systeem, en bovenal het niet langer dan nodig ter plaatse houden van een urinesonde (Olin en Barges, 2015; Weese et al., 2019). Het is niet aan te raden om urinesondes routinematig te vervangen om bacteriurie of cystitis te voorkomen. Het is evenmin aangewezen om de urine regelmatig te screenen op pyurie, hematurie of bacteriurie, aangezien deze aanwezig kunnen zijn zonder dat er effectief sprake is van cystitis. De aanwezigheid van SKB is dan ook geen reden om een urinesonde te vervangen, aangezien dit net het risico op UWI verhoogt door contaminatie of trauma tijdens de sondage (Weese et al., 2019).

Een urinecultuur bij een gesondeerd dier wordt enkel aangeraden indien er klinische klachten ontstaan horend bij bacteriële cystitis of pyelonefritis en gebeurt bij voorkeur op cystocentese-urine (Weese et al., 2019). Antibioticumbehandeling van subklinische urinesonde-geassocieerde bacteriurie werkt namelijk alleen maar de ontwikkeling van resistente organismen in de hand, waardoor dit sterk wordt afgeraden (Köves et al., 2017a), net als het profylactisch toedienen van antibiotica ter preventie van het ontstaan van bacteriurie of cystitis bij gesondeerde dieren (Weese et al., 2019).

Routinecultuur van de urine na het verwijderen van een urinesonde wordt evenmin geadviseerd, tenzij er toch lagere-urinewegsymptomen zouden ontstaan of persisteren nadat de urinesonde werd verwijderd. Indien een cultuur van cystocentese-urine vervolgens positief blijkt, kan het dier met antibiotica worden behandeld, zoals beschreven voor sporadische bacteriële cystitis (Weese et al., 2019).

\section{CONCLUSIE}

Er is de afgelopen jaren heel wat veranderd wat de richtlijnen voor het behandelen van bacteriële UWIs 
bij honden en katten betreft. Zo wordt het screenen voor en behandelen van bacteriurie in de afwezigheid van klinische klachten niet langer geadviseerd, ook niet bij dieren met predisponerende aandoeningen. In de gevallen waar wel therapie met een antibioticum is geïndiceerd (door de aanwezigheid van geassocieerde symptomen), wordt naar analogie met de humane geneeskunde een minder lange behandelingsduur aanbevolen. Voor honden en katten met sporadische bacteriële cystitis volstaat een antibioticumtherapie van drie tot vijf dagen. Ook bij herval volstaat een antibio- ticumbehandeling van drie tot vijf dagen in combinatie met het aanpakken van de onderliggende oorzaak indien mogelijk.

Idealiter wordt de aanwezigheid van een bacteriële UWI steeds bevestigd door middel van urinecultuur, bij voorkeur van urine verkregen via cystocentese. Door antimicrobiële middelen enkel bij bevestigde gevallen van een UWI in te zetten en antibiotica niet onnodig lang toe te dienen kunnen zowel kosten, bijwerkingen alsook het risico op de ontwikkeling van antibioticumresistentie worden gereduceerd.

\section{Addendum: Het maken van een preparaat van urinesediment voor microscopisch onderzoek (tekst naar: Reppas en Foster, 2016)}

Nadat de spuit met urine enkele keren wordt gezwenkt om de inhoud goed te mengen, volstaat het om $3 \mathrm{ml}$ urine in een kegelvormig buisje aan lage snelheid te centrifugeren - meer bepaald gedurende 3-5 minuten aan 1000-1500 toeren/minuut ( of $450 \mathrm{xg}$ ) - waarna de overgrote meerderheid van het supernatans voorzichtig wordt weggegoten.
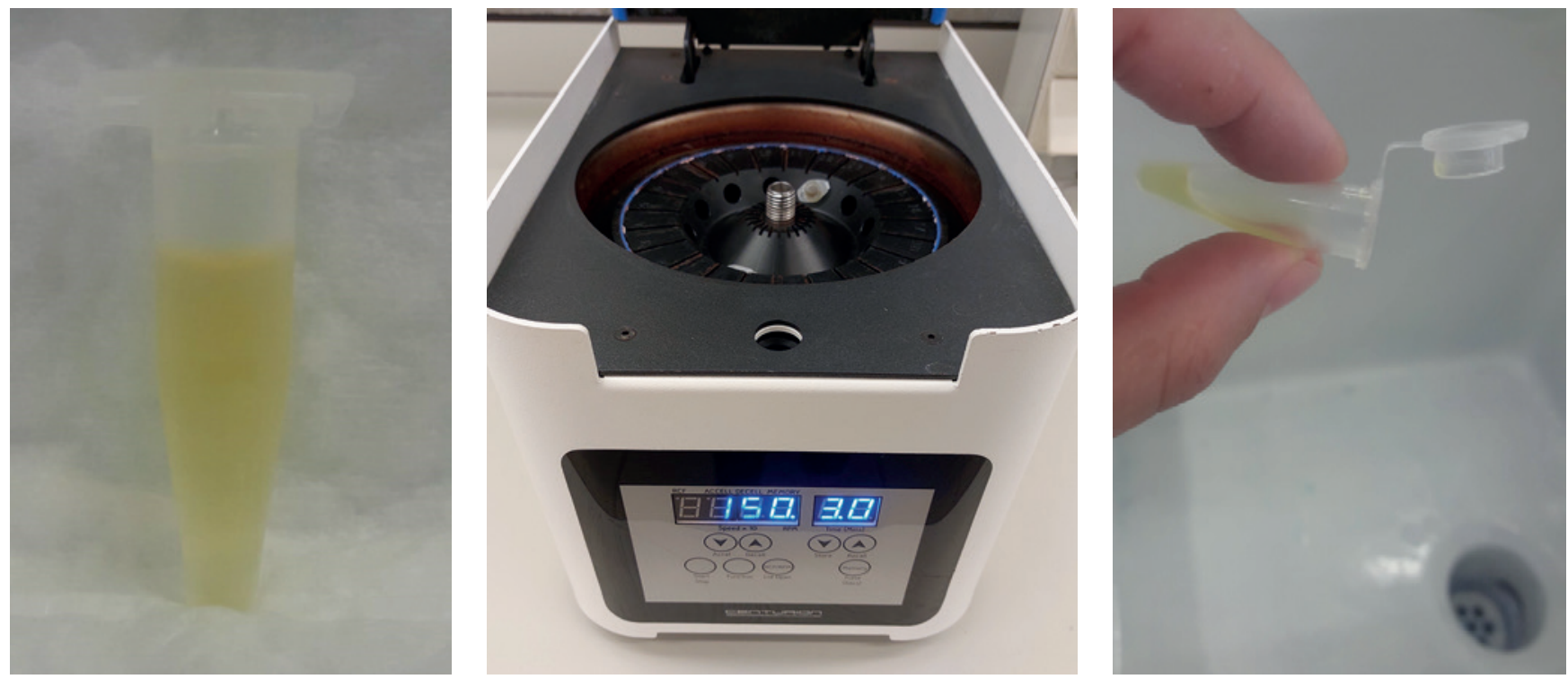

Vervolgens wordt de "pellet" die zich nog onderin het buisje bevindt, terug opgelost in de resterende druppel supernatans (de bovendrijvende vloeistof), door met de vinger herhaaldelijk onderaan tegen het buisje te tikken. Deze druppel sediment wordt op een draagglaasje aangebracht en wordt bedekt met een dekglaasje. Vervolgens wordt dit onder de microscoop bekeken met aansluitend een x 10 objectief (voor cilinders en kristallen) en een $\mathrm{x}$ 40 objectief (voor leukocyten, erytrocyten en bacteriën). Het diafragma wordt bij het bekijken van een dergelijk nat preparaat het beste gesloten om het contrast te verbeteren.
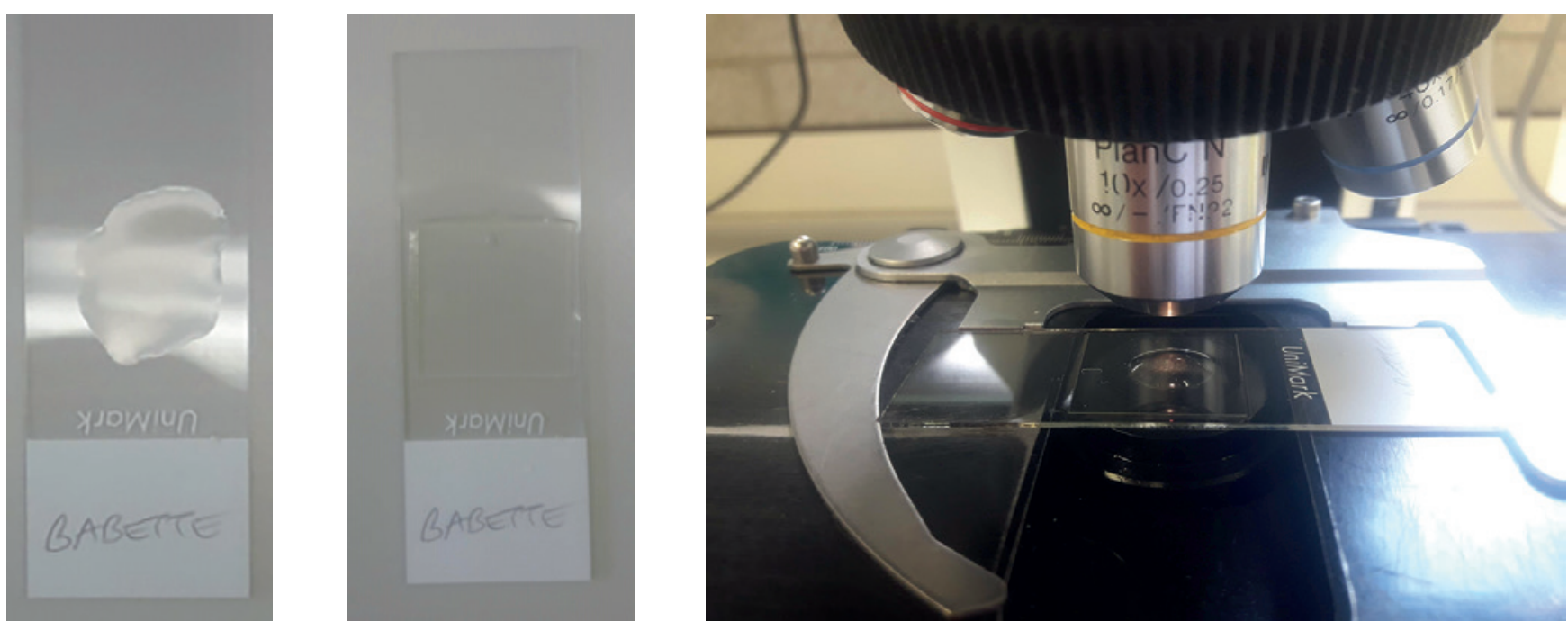


\section{REFERENTIES}

Baigi S.R., Vaden S.L., Olby N.J. (2017). The frequency and clinical implications of bacteriuria in chronically paralyzed dogs. Journal of Veterinary Internal Medicine 31(6), 1790-1795.

Bonkat G., Pickard R., Bartoletti R., Cai T., Bruyère F., Geerlings S.E., Köves B., Wagenlehner F. (2018). Guidelines on Urological Infections, European Association of Urology (EAU). https://uroweb.org/wp-content/uploads/ EAU-Guidelines-on-Urological-Infections-2018-largetext.pdf.

Bonkat G., Bartoletti R., Bruyère F., Cai T., Geerlings S.E., Köves B., Schubert S., Wagenlehner F. (2021). Guidelines on Urological Infections, European Association of Urology (EAU). https://uroweb.org/wp-content/uploads/ EAU-Guidelines-on-Urological-infections-2021.pdf.

Byron J.K. (2019). Urinary tract infection. Veterinary Clinics of North America Small Animal Practice 49, 211221.

Cai T., Mazzoli S., Mondaini N., Meacci F., Nesi G., D’Elia C., Malossini G., Boddi V., Bartoletti R. (2012). The role of asymptomatic bacteriuria in young women with recurrent urinary tract infections: to treat or not to treat? Clinical Infectious Diseases 55(6), 771-777.

Cai T., Nesi G., Mazzoli S., Meacci F., Lanzafame P., Caciagli P., Mereu L., Tateo S., Malossini G., Selli C., Bartoletti R. (2015). Asymptomatic bacteriuria treatment is associated with a higher prevalence of antibiotic resistant strains in women with urinary tract infections. Clinical Infectious Diseases 61(11), 1655-1161.

D’Anjou M.A., Bédard A., Dunn M.E. (2011). Clinical significance of renal pelvic dilatation on ultrasound in dogs and cats. Veterinary Radiology and Ultrasound 52(1), 88-84.

Fisher, H., Oluboyede, Y., Chadwick, T., Abdel-Fattah, M., Brennand, C., Fader, M., Harrison, S., Hilton, P., Larcombe, J., Little, P., et al., (2018). Continuous low-dose antibiotic prophylaxis for adults with repeated urinary tract infections (AnTIC): a randomised, open-label trial. The Lancet Infectious Diseases 18, 957-968.

Gáygor I., Bleidorn J., Kochen M.M., Schmiemann G., Wegscheider K., Hummers-Pradier E. (2015). Ibuprofen versus fosfomycin for uncomplicated urinary tract infection in women: randomised controlled trial. The BMJ 35 , h6544.

González M.J., Zunino P., Scavone P., Robino L. (2020). Selection of effective antibiotics for uropathogenic Escherichia coli intracellular bacteria reduction. Frontiers in Cellular and Infection Microbiology 10, 542755.

Jessen L.R., Sørensen T.M., Bjornvad C.R., Nielsen S.S., Guardabassi L. (2015). Effect of antibiotic treatment in canine and feline urinary tract infections: a systematic review. The Veterinary Journal 203(3), 270-277.

Köves B., Magyar A., Tenke P. (2017). Spectrum and antibiotic resistance of catheter-associated urinary tract infections. GMS Infectious Diseases (5), 1-5.

Köves B., Cai T., Veeratterapillay R., Pickard R., Seisen T., Lam T.B., Yuhong Yuan C., Bruyere F., Wagenlehner F., Bartoletti R., Geerlings S.E., Pilatz A., Pradere B., Hofmann F., Bonkat G., Wullt B. (2017). Benefits and harms of treatment of asymptomatic bacteriuria: a systematic review and meta-analysis by the European Association of Urology Urological Infection Guidelines Panel. European Urology 72(6), 865-868.
Kutzler M.A. (2016). Prostatic diseases. In: Ettinger, S.J., Feldman, F.C., Cote, E. (editors). Textbook of Veterinary Internal Medicine. Eighth edition, Saunders Elsevier, St. Louis, USA, 2031-2036.

Marynissen S.J.J., Willems A.L., Paepe D., Smets P.M.Y., Picavet P., Duchateau L., Daminet S. (2017). Proteinuria in apparently healthy elderly dogs: persistency and comparison between free catch and cystocentesis urine. Journal of Veterinary Internal Medicine 31(1), 93-101.

Nizanski W., Levy X., Ochata M., Pasikowska J. (2014). Pharmacological treatment for common prostatic conditions in dogs - Benign prostatic hyperplasia and prostatitis: an update. Reproduction in Domestic Animals 49(2), 8-15.

Olin S.J., Bartges J.W. (2015). Urinary tract infections: treatment/comparative therapeutics. Veterinary Clinics of North America Small Animal Practice 45(4), 721-746.

Paepe D., Verjans G., Duchateau L., Piron K., Ghys L., Daminet S. (2013). Routine health screening: findings in apparently healthy middle-aged and old cats. Journal of Feline Medicine and Surgery 15(1), 8-19.

Patterson C.A., Bishop M.A., Pack J.D, Cook A.K., Lawhon S.D. (2016). Effects of processing delay, temperature, and transport tube type on results of quantitative bacterial culture of canine urine. Journal of the American Veterinary Medical Association 248(2), 183-187.

Piech T.L., Wycislo K.L. (2019). Importance of urinalysis. Veterinary Clinics of North America Small Animal Practice 49(2), 233-245.

Provoost J., Defauw P., Daminet S., Duchateau L., Paepe D. (2019). De rol van ervaring bij de beoordeling van urinesediment bij hond en kat. Vlaams Diergeneeskundig Tijdschrift 88(4), 201-206.

Reppas G., Foster S.F. (2016). Practical urinalysis in the cat. Journal of Feline Medicine and Surgery 18(3), 190202.

Reppas G., Foster S.F. (2016). Practical urinalysis in the cat. Journal of Feline Medicine and Surgery 18(5), 373385.

Sævik B.K, Trangerud C., Ottesen N., Sørum H., Eggertsdóttir A.V. (2011). Causes of lower urinary tract disease in Norwegian cats. Journal of Feline Medicine and Surgery 13(6), 410-417.

Smee N., Grauer G.F., Schermerhorn T. (2011). Investigations into the effect of cranberry extract on bacterial adhesion to canine uroepithelial cells. Journal of Veterinary Internal Medicine 25, 716-717.

Smee N., Loyd K., Grauer G.F. (2013). UTIs in small animal patients. Journal of the American Animal Hospital Association 49(2), 83-94.

Sørensen T.M., Bjørnvad C.R., Cordoba G., Damborg P., Guardabassi L., Siersma V., Bjerrum L., Jessen L.R. (2018). Effects of diagnostic work-up on medical decision-making for canine urinary tract infection: an observational study in Danish small animal practices. Journal of Veterinary Internal Medicine 32, 743-751.

Sørensen T.M., Bjørnvad C.R., Damborg P., Guardabassi L., Bjerrum L., Jessen L.R. (2019). In-house culture and susceptibility testing reduce antibiotic over-prescription in dogs with suspected cystitis - A randomized controlled trial. Research Communication of the 28th ECVIM-CA Congress. Journal of Veterinary Internal Medicine 33(2), 1092.

Sørensen T.M., Holmslykke M., Nordlund M., Siersma V., Jessen L.R. (2019). Pre-test probability of urinary tract 
infection in dogs with clinical signs of lower urinary tract disease. The Veterinary Journal 247, 65-70.

Swenson C.L., Boisvert A.M., Gibbons-Burgener S.N., Kruger J.M. (2011). Evaluation of modified Wright-staining of dried urinary sediment as a method for accurate detection of bacteriuria in cats. Veterinary Clinical Pathology 40(2), 256-264.

Sykes J.E., Hartmann K., Lunn K.F., Moore G.E., Stoddard R.A., Goldstein R.E. (2011). 2010 ACVIM small animal consensus statement on leptospirosis: diagnosis, epidemiology, treatment, and prevention. Journal of $\mathrm{Ve}$ terinary Internal Medicine 25(1), 1-13.

Timmermans J., Van Goethem B., de Rooster H., Paepe D. (2019). Medical treatment of urinary incontinence in the bitch. Vlaams Diergeneeskundig Tijdschrift 88(1), 3-8.

Van Dongen A.M. (2016). Pyelonephritis. In: Ettinger, S.J., Feldman, F.C., Cote, E. (editors). Textbook of Veterinary Internal Medicine. Eighth edition, Saunders Elsevier, St. Louis, USA, 1977-1981.

Wan S.Y., Hartmann F.A., Jooss M.K., Viviano K.R. (2014). Prevalence and clinical outcome of subclinical bacteriuria in female dogs. Journal of the American Veterinary Medical Association 245(1), 106-112.

Weese J.S., Blondeau J.M., Boothe D., Breitschwerdt E.B., Guardabassi L., Hillier A., Lloyd D.H., Papich M.G., Rankin S.C., Turnidge J.D., Sykes J.E. (2011). Antimicrobial use guidelines for treatment of urinary tract disease in dogs and cats: antimicrobial guidelines working group of the International Society for Companion Animal Infectious Diseases. Veterinary Medicine International 263768, 1-9.

Weese J.S., Blondeau J.M., Boothe D., Guardabassi L., Gumley N., Papich M.G., Jessen L.R., Lappin M., Rankin S.C., Westropp J.L., Sykes J.E. (2019). International Society for Companion Animal Infectious Diseases (ISCAID) guidelines for the diagnosis and management of bacterial urinary tract infections in dogs and cats. The Veterinary Journal 247, 8-25.

White J.D., Cave N.J., Grinberg A., Thomas D.G., Heuer C. (2016). Subclinical bacteriuria in older cats and its association with survival. Journal of Veterinary Internal Medicine 30(6), 1824-1829.

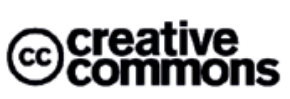

2021 by the authors. Licensee Vlaams Diergeneeskundig Tijdschrift, Ghent University, Belgium. This article is an open access article distributed under the terms and conditions of the Creative Commons Attribution (CC BY) license (http://creativecommons.org/licenses/by/4.0/).

\section{Nieskruidwortel in het scrotum: een paardenmiddel}

Toen de pest in Lyon woedde, paste een monnik een wel zeer drastische paardenremedie op zich zelf toe. Hij doorboorde zijn scrotum en stak een stukje nieskruidwortel in de wonde, zoals men bij paarden pleegt te doen. Op die manier mocht hij zijn mannelijke attributen als gevrijwaard van de pest beschouwen.

Montanus. T. (Thomas vanden Berghe, 1669). Over de pest in Brugge. Vertaald in Montanus Tijdingen, 2008.

Over de toepassing van de sterk irriterende nieskruidwortel (Helleborus) als 'etterdracht' om ontsteking op te wekken en 'het kwaad uit te drijven', zie VDT, 2015, jg. 84, p. 101. 